\title{
Perspectives On The LEED (Leadership In Energy And Environmental Design) System As A Green Certification Standard
}

Alexander M Tolksdorf, University of Detroit Mercy, USA

Evan A. Peterson, University of Detroit Mercy, USA

Gregory W. Ulferts, University of Detroit Mercy, USA

\begin{abstract}
As we begin to reach the limits of Earth's biosphere, ensuring that sustainable practices are integrating into new buildings and into older buildings are crucial to remove unsustainable strains on the environment. This paper seeks to examine the merits and disadvantages of LEED as a certification system in the context of environmental sustainability. While there does seem to be legitimate criticism of the LEED system, it does serve to bring and legitimize sustainable development to an area that has a profound and continual effect on the environment. The systems should be continuously examined and revamped in the context of improving the integration of environmental sustainability into commercial and residential development. LEED has the opportunity to be revamped, improved, and to become a powerful force in promoting environmental sustainability in construction.
\end{abstract}

Keywords: LEED; Environmental Sustainability; Green Certification Standard

\section{INTRODUCTION}

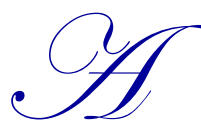

common definition of "sustainable development" comes from the United Nations Brundtland Commission report Our Common Future in 1987, which defined the term as "...development which meets the needs of current generations without compromising the ability of future generations to meet their own needs" (Bärlund). The definition suggests that sustainability development and the concept of sustainability are a combination of a belief set (that current development should not harm future generations) and subsequent actions across social, economic, and environmental domains. Environmental sustainability is discussed at length in our social and political spheres today. Once an issue relegated to "treehuggers" removed from the center of political discourse, environmental issues today often come to the forefront of national debate. It can be said that the documentary An Inconvenient Truth (2006) has been a large driver of the increased environmental awareness indeed, it even has been adapted into the curriculum of some colleges and high schools - and this awareness has thrust a once backburner issue into the forefront of the minds of the general public. As such, the issue is set at odds with economic growth. Lester Brown, in the first chapter of Plan B 4.0, states that "As of 2009, the global demand placed upon natural systems surpassed sustainable yield capacity by almost 30\%" (Maddison).

Yet at the same time, the act of embracing environmental sustainability and implementing eco-friendly practices attaches a positive, conscientious label to those involved. Certifications are now available to those who seek to construct or renovate in an environmentally sustainable way. One such certification is LEED - Leadership in Energy and Environmental Design. Addressing energy efficiency and eco-friendliness is crucial to environmental sustainability: in a 2008 report by the U.S. Department of Energy, “...the nation's 114 million households and more than 4.7 million commercial buildings consume more energy than the transportation or industry sectors, accounting for nearly 40 percent of total U.S. energy use" ("Energy Efficiency Trends in Residential and Commercial Buildings"). Brown indicates in the fourth chapter of Plan B 4.0 that in the United States commercial building sector 
alone, buildings account for $72 \%$ of electrical use and $38 \%$ of carbon dioxide emissions. On a global scale, commercial building construction accounts for $40 \%$ of materials use (US Green Building Council).

Given that, at least in 2008 , over “...70 percent of U.S. electricity is generated by burning coal, petroleum, or natural gas; another 20 percent is generated by nuclear power stations; and less than 9 percent comes from renewable sources..." ("Energy Efficiency Trends in Residential and Commercial Buildings") it is crucial to promote energy efficient and eco-friendly practices in commercial, residential, and other construction in the United States. As noted by Lester Brown in the introduction to chapter four of Plan B 4.0, the world is undergoing an energy revolution, involving a shift to new energy-efficient technologies and a transition away from, "an economy powered by oil, coal, and natural gas to one powered by wind, solar, and geothermal energy." As we begin to reach the limits of Earth's biosphere, ensuring that sustainable practices are integrating into new buildings and into older buildings are crucial to remove unsustainable strains on the environment. This paper seeks to examine the merits and disadvantages of LEED as a certification system in the context of environmental sustainability.

\section{Leadership in Energy and Environmental Design (LEED)}

Originally developed in 1998 by the U.S. Green Building Council (USGBC), LEED certification is currently divided among several rating systems, based on different forms of construction. These rating systems include: new construction and major renovations, existing buildings operation and maintenance, commercial interiors, core shell and development, retail, schools, homes, neighborhood development, and healthcare ("Rating Systems"). The LEED rating (Certified, Silver, Gold, and Platinum) is earned based on the number of points earned from the number of credit activities performed. Credit activities are categorized as follows:

- Main credit categories: sustainable sites credits, water efficiency credits, energy \& atmosphere credits, materials \& resources credits, and indoor environmental credits

- $\quad$ Additional "neighborhood development" credit categories: smart location \& linkage credits, neighborhood pattern \& design credits, and green infrastructure \& buildings credits

- $\quad$ Additional "homes" credit categories: location \& linkage credits and awareness \& education credits

- Bonus credits: innovation in design or innovation in operations credits and regional priority credits ("Ratings Systems")

The current iteration of LEED certification, LEED v4 introduced in 2012, is weighted. LEED certification has been weighted since LEED v3 was introduced in 2009 (Owens et al. 2). LEED v3 used a 100 point scale with 10 available bonus points and based point allocations off of the Tool for Reduction and Assessment of Chemical and Other Environmental Impacts (TRACI) impact categories from the U.S. Environmental Protection Agency, the EPA (Holmes). In an effort to shift LEED certification to doing "more good" rather than doing "less bad" as well as employ a weighting system that more clearly reflected the mission of LEED and USGBC, a new weighting scale was developed through USGBC introducing its own "impact categories" (Holmes). These impact categories are, according to Holmes:

- $\quad$ Reverse contribution to global climate change

- $\quad$ Enhance individual human health and well-being

- $\quad$ Protect and restore water resources

- $\quad$ Protect, enhance and restore biodiversity and ecosystem services

- $\quad$ Promote sustainable and regenerative material resources cycles

- $\quad$ Build a greener economy

- $\quad$ Enhance social equity, environmental justice, community health and quality of life

The impact categories are given relative weights. "As Chrissy Macken, assistant project manager of LEED v4 at USGBC, described it, 'If it is a large-scale global problem where the built environment is a big part of the problem, and can be a big part of the solution, then it gets weighted heavily.' For example, climate change is a global problem to which the built environment contributes heavily, and we know it can contribute to solutions, so that category was weighted most heavily in this exercise" (Holmes). A database of associations between LEED 
credit options and impact categories was then built by the USGBC, which determined, after some analysis, how many points each credit received (Holmes).

One interesting aspect of the LEED certification system is the broad eco mindset employed in its certification paths. If, for instance, one examines the LEED credit database (using the school - existing building renovation path), the variety of credit opportunities is extensive. Beyond credits designed to reduce energy consumption, water consumption, and waste - a standard in environmental sustainability, the system also encourages eco-friendly habits that benefit the users of the building, like improving interior air quality, lighting, and providing environmental tobacco smoke control, and well as more unorthodox eco-friendly habits such as elimination of heat islands and managing rainwater. Further, if one examines the "managing rainwater" credit, one can clearly see the level of detail and intent of the certification process: “... [t] o reduce runoff volume and improve water quality by replicating the natural hydrology and water balance of the site, based on historical conditions and undeveloped ecosystems in the region" ("Rainwater Management." Thus, while LEED seeks to meet the traditional goals of environmental construction in the sense of energy usage reduction, it also seeks to promote sustainable habits that allow buildings to conform and blend into the environment. Through the promotion of transportation linkages, LEED also seeks to incorporate social sustainable actions into green building.

\section{Benefits of Green Buildings to Business}

As noted by Lester Brown in the fourth chapter introduction of Plan B 4.0, "Closely associated with the movement to improve energy efficiency and develop renewable sources of energy is the realization that the countries and companies that are at the forefront of developing new energy technologies will have a strong competitive advantage in world markets" (Brown, 2008). Nevertheless, it is often argued that eco-friendly construction is costly and certification processes are burdensome. However, it is relatively well documented that "green" construction is beneficial to those constructing the new building and the community as a whole. Even as early as 2003, the benefits of green construction were being documented. In The Costs and Financial Benefits of Green Buildings, a study prepared for the California Sustainable Building Task Force, such benefits are identified:

"The benefits of building green include cost savings from reduced energy, water, and waste; lower operations and maintenance costs; and enhanced occupant productivity and health....analysis of these areas indicates that total financial benefits of green buildings are over ten times the average initial investment required to design and construct a green building. Energy savings alone exceed the average increased cost associated with building green" (Kats 8).

Moreover,

"Additionally, the relatively large impact of productivity and health gains reflects the fact that the direct and indirect cost of employees is far larger than the cost of construction or energy. Consequently, even small changes in productivity and health translate into large financial benefits" (Kats 8).

Brown discusses the benefits as well in chapter four of Plan B 4.0. For example, given that a building may last between 50-100 years, or longer, it's often incorrectly believed that the process of cutting carbon emissions in the building sector is by nature a long term endeavor. However, this is far from the case, as an energy retrofit of older inefficient buildings can cut energy use and energy bills by 20-50\% (Mazria; Clinton Foundation).

Moving closer to the present, the business benefits of promoting environmentally sustainable practices have not subsided. Entrepreneur magazine discussed the wide-ranging benefits of "going green" at length in a July 2013 article. The author indicates that the simple cost savings incentive of reduced energy consumption has been superseded by a variety of other tangible and non-tangible benefits. "Cost savings are evolving into revenue generation,' says Lauren Kelley Koopman, a director for PwC's Sustainable Business Solutions practice. 'Sustainability is next-generation business thinking because it creates value, attracts customers, retains employees and improves capital and funding" (Krotz). Brown elaborates further in Plan B 4.0, chapter four. For example, according to a study commissioned by the state of California, certification resulted in an increase to construction costs by $\$ 4$ per square foot. However, due to the resulting reductions in operating costs, employee absenteeism, and 
turnover, along with increased productivity, "the standard and silver certified buildings earned a profit over the first 20 years of $\$ 49$ per square foot, and the gold and platinum certified buildings earned $\$ 67$ per square foot" (Feder). These tangible cost benefits are not lost on the business community, as the amount of commercial building space that has been certified or registered for certification approval reaches nearly 5 billion square feet of floor space (US Green Building Council). As noted by Davis Langdon, "Going green is future-proofing your asset" (Langdon). This mirrors the underpinnings of LEED certification; the certification plans do not solely focus on energy efficiency, but rather on oneness with the environment at large.

Another interesting aspect is the value-added generated by environmentally friendly practices. The July 2013 Entrepreneur article provides the example of Enviro-Logs, a company based near Albany, Georgia that manufactures eco-friendly fireplace logs " ...burn cleaner than wood, emitting 30 percent less greenhouse gases, 80 percent less carbon dioxide and 86 percent less creosote, while still producing 50 percent more heat per pound" (Krotz). The company found that customers, when educated and made aware about the products, will be willing to pay a premium for the clean-burning logs (Krotz). With regards to LEED certification and the "eco-labeling" it provides, research has shown that tenants are willing to pay a rent premium for a LEED certified building - over other certifications like Energy Star and no certification.

"Similar to other product markets, both mandatory and voluntary eco-labels have become increasingly important in the commercial real estate sector. There are strong a priori grounds to expect differences in occupier demand for eco-labeled offices relative to non-labeled offices. It is generally accepted that there are benefits associated with environmentally responsible offices. Occupiers can gain tangibly from lower utility costs and incentives or subsidies and, perhaps less tangibly, from improvements in business performance and marketing benefits. In addition, from an investor's perspective there are a number of channels by which superior environmental performance can influence the financial performance of the asset. These are mainly associated with higher incomes (rental premiums, higher occupancy levels), costs reductions (lower operating expenditure, lower vacancy rates), and reduced risk premia" (Fuerst and McAllister 61-62).

Further,

"It is particularly striking that the median occupancy rate for multi-tenanted LEED-labeled offices is $99 \%$. Overall, the results suggest there is an occupancy premium of approximately $8 \%$ for LEED-labeled offices. The quantile regression finds that the LEED label has a significant positive effect on occupancy level for most deciles of LEED offices" (Fuerst and McAllister 62).

Indeed, while the research concludes also that historical data is relatively scarce (since the idea of ecolabeling or certification is so new) and that the study cannot exactly identify the drivers of these premiums, it does show that business benefits can be extracted from environmentally sustainable practices. Therefore, economic and environmental objectives might not always be at odds, and sustainability may not need to be regulated into existence, as is the case for countries that are taking bolder steps. Brown indicates this as well in the fourth chapter of Plan B 4.0. For example, as of 2009 Germany requires that all new buildings must either receive at least $15 \%$ of space and water heating from renewable energy, or they must work to dramatically improve energy efficiency (Wustlich, Müller, and Radtke).

\section{Problematic Elements within LEED}

Sustainable practices can be encouraged through a capitalism system once companies and individuals are aware of the tangible and intangible benefits. LEED certification is one such method of actualizing the benefits of and legitimizing the practice of sustainable development in construction and renovation. Moreover, LEED certifications can translate into substantial tax benefits (Schnaars and Morgan). While a few of the merits of LEED certification have been discussed, there are problematic elements as well. ArchDaily, an online architecture news source, discusses the merits (many of which have been mentioned above) and the flaws in the system. The flaws include: 
- $\quad$ "LEED's status symbol and point system encourage you to "game" the system (and not think about the environment at all)

- $\quad$ LEED is difficult \& expensive to do on your own

- $\quad$ LEED is an isolated evaluation of a building's design, which ignores context and performance

- If LEED becomes a mandate, it loses its adaptability" (Quirk)

The first point is discussed by numerous sources - the fact is, the LEED (prior to LEED v3 in 2009) system was unweighted (Quirk), so there was really no extra benefit in completing a capital-intensive green project for points versus completing inexpensive and "easy" green projects for the same number and weight of points. Indeed, the idea of weighting was "a new innovation" in the 2009 system (Owens et al. 2). As the author explains about the earlier system:

“...if a building includes a bike rack, it will earn a point. Fair enough, it's an easy to way to encourage alternative transportation and employee health. The extremely costly redevelopment of a "brownfield," an area contaminated by hazardous substances? Also one point...Tough choice" (Quirk).

USAToday elaborates on this criticism:

“A USA TODAY review of 7,100 LEED-certified commercial buildings shows that designers target the easiest and cheapest green points by trying to create pleasant and healthful office spaces; using common building materials; or taking steps with an unknown effect, such as providing preferred parking for fuel-efficient cars, bike racks and showers, and posting educational displays about the building” (Schnaars and Morgan).

Further,

“'People have a tendency to buy points — they buy that bike rack even though there's no value in it,' said Kansas City, Mo., architect Bob Berkebile, who helped create LEED in the 1990s and remains a strong proponent. 'It's unfortunate. That's just where we are at this time"' (Schnaars and Morgan).

Indeed, when the base-level certificate of earlier systems of LEED required a score of 40 out of 100 points, simple, inexpensive actions that did not necessarily have a direct positive impact on the environment added up to the certification threshold. USAToday identified that $99.7 \%$ of LEED buildings earned a point simply by having a LEED expert as a member of the design team. $90 \%$ of the buildings earned points through using indoor paints, adhesives, and floors that emit fewer contaminants, which although beneficial to employees, does not directly improve the environment outside the building. Moreover, these materials are widely used (Schnaars and Morgan). 91\% of the buildings earned points by utilizing recycled materials, like steel and concrete (often, these materials are recycled), which are standard building materials (Schnaars and Morgan). In contrast, “...only 14\% of buildings generate renewable energy, and $12 \%$ include major water-reduction steps such as using waterless urinals or treating sewage on site" (Schnaars and Morgan). In short, the system allows certification seekers to achieve a LEED status with actions that do not add value or benefit the environment or by complying with industry standards. Perhaps it can be best described as (intentionally or unintentionally) "seeing the trees, but missing the forest."

The second is also fairly self-evident; it can initially be costly and difficult to implement. The last two points, however, are interesting criticisms that strike at the foundation of the system. The third point is considered to be a fatal flaw by some (Quirk); LEED certification does not necessarily consider the context of a certification. LEED advocates have not necessarily denied this - as stated earlier, previous iterations of LEED have been focused on reducing the "bad" rather than promoting the "good" as a policy position. That is to say, one can build the most "sustainable" resort hotel (by obtaining large numbers of LEED credits) in the most un-sustainable context - i.e. a desert. USAToday cites the Palazzo hotel in Las Vegas as the prime example; the hotel was LEED certified in 2008, but did so by "...exploring the boundaries of the way the rating system should be applied" (Schnaars and Morgan). Moreover, LEED is not a performance measurement tool (Quirk). The last point suggests that as the certification becomes more mainstream, governments will begin to subsidize it and businesses will scramble to attain it, ensuring developers will “...blindly follow its requirements without truly questioning them at all” (Quirk). 


\section{Recommendations}

Criticisms raised regarding the weighting system, while certainly valid, have been addressed through the introduction of LEED v4. The newest iteration, to some extent, was designed to combat the "gaming of the system," or as is known commonly known "greenwashing." ArchDaily explains some of the attempts LEED v4 has made in combating "greenwashing:"

"In previous iterations of LEED, it was possible to focus on easy, cheap credits to obtain LEED status for a building, while ignoring credits that might have more impact but were hard to achieve. This led some to accuse LEED of enabling greenwashing, projects that claimed to be green when really they were doing the minimum possible to become LEED certified.

In LEED v4, the USGBC has gone some way to combat this by introducing new prerequisites such as metering and recording the building's energy and water use. These factors of building performance can no longer be ignored as difficult, time-consuming credits to achieve - they must be included to achieve LEED status.

Beth Heider also adds that 'while LEED 2009 weighted points to encourage projects to do less harm, LEED v4 is aspirational in weighting and developing credits to encourage projects to do more good"” (Stott).

Further, the weighted system coupled with the stated desire to move LEED certificate closer to the original mission of the program (recall comments from Chrissy Macken mentioned previously), will likely help to alleviate the contextual paradox that faced earlier LEED programs. Thus, LEED v4 appears to be promising in alleviating some major concerns expressed with previous LEED systems. While LEED still is not a performance measurement tool, the weighting system may correct the "blind following" criticism. LEED has largely become mainstream and arguably has caused developers to blindly implement requirements to achieve certification levels that please their clients. However, it is largely these actions that have spurred the continual and increasing criticism of LEED, and perhaps influenced the development of LEED v4. Developers may still blindly follow requirements, but the requirements are likely more challenging and environment-centric. However, one problematic element that will continue (to at least 2015) is that because LEED v4 has been feared as too big of a change, the USGBC is allowing LEED v3 to be used through 2015 alongside of LEED v4, ArchDaily suggests that having two active iterations is a retroactive step regarding "gaming the system" (Stott). However, as LEED v4 was implemented just recently in 2012, it still may be too early to determine if additional or more complex problems exist within the system.

While there does seem to be legitimate criticism of the LEED system, it does serve to bring and legitimize sustainable development to an area that has a profound and continual effect on the environment. These positives should not be ignored. The systems should be continuously examined and revamped in the context of improving the integration of environmental sustainability into commercial and residential development, and as long as the USGBC continues to focus on being more mission-centric and doing "good" rather than doing "less bad," LEED has the opportunity to be revamped, improved, and to become a powerful force in promoting environmental sustainability in construction.

\section{AUTHOR INFORMATION}

Alexander Tolksdorf is a financial analyst at the Ford Motor Company, having completed his MBA with a concentration in accounting in May 2014 from the University of Detroit Mercy. He is the immediate past president of the UDM Alpha Xi chapter of Beta Alpha Psi, the international honor organization for financial information students and professionals, and is working toward earning his CPA license. Prior to working at Ford, Alexander worked at a turnaround management consulting firm, O'Keefe \& Associates.

Evan A. Peterson, J.D., M.B.A., is a licensed attorney, Lecturer in Business Law, and Director of Undergraduate Business Programs in the College of Business Administration at the University of Detroit Mercy. His research activities have included publication on diverse topics related to business law, ethics, and sustainability. Mr. Peterson has served as legal counsel for the International Association of Jesuit Business Schools, Alpha Iota Delta, and the Business Leadership Network of Michigan. 
Gregory W. Ulferts, D.B.A, is a Professor of Decision and Systems Sciences in the College of Business Administration. His scholarly activities have included research and publication on various topics related to management information systems, financial management, decision sciences, small business administration, and international business. Dr. Ulferts has served as a consultant in business and government in areas such as strategic and technology planning, operations and procurement management, analysis and design of systems, and business development. He is a certified Cost Estimator/Analyst and has worked on U.S. Department of Labor, U.S. Department of Commerce and U.S. Department of Transportation projects.

\section{REFERENCES}

1. Bärlund, Kaj. "Sustainable Development - Concept and Action." United Nations Economic Commission for Europe. United Nations, n.d. Web. 13 Mar. 2014. <http://www.unece.org/oes/nutshell/20042005/focus_sustainable_development.html>.

2. Brown, Lester R. "Creating New Jobs, Cutting Carbon Emissions, and Reducing Oil Imports by Investing in Renewable Energy and Energy Efficiency." Plan B Updates. Earth Policy Institute, 11 Dec. 2008. Web. 09 Mar. 2014. <http://www.earth-policy.org/plan_b_updates/2008/update80>.

3. Brown, Lester R. Plan B 4.0: Mobilizing to save Civilization. New York: W.W. Norton, 2009. Print.

4. $\quad$ "Energy Efficiency Trends in Residential and Commercial Buildings." Office of Energy Efficiency and Renewable Energy. U.S. Department of Energy, Oct. 2008. Web. 15 Oct. 2013.

<http://apps1.eere.energy.gov/buildings/publications/pdfs/corporate/bt_stateindustry.pdf>.

5. Clinton Foundation. Energy Efficiency Building Retrofit Program Fact Sheet. New York: Clinton Foundation, May 2007. Print.

6. Davis Langdon. Cost and Benefit of Achieving Green Buildings. Rep. Sydney: Davis Langdon \& Seah International, 2007. Print.

7. $\quad$ Feder, Barnaby J. "Environmentally Conscious Development." The New York Times 25 Aug. 2004: n. pag. Print.

8. Fuerst, Franz, and Patrick McAllister. "An Investigation of the Effect of Eco-Labeling on Office Occupancy Rates." JORSE 1.1 (2009): 49-64. CoStar.com. CoStar Group, 2009. Web. 15 Oct. 2013. <http://www.costar.com/josre/JournalPdfs/03-Effect-Eco-Labeling.pdf>.

9. Holmes, Selina. "Leed V4: Built to Perform." EDCmag.com. BNP Media, 2 Apr. 2013. Web. 10 Mar. 2014. <http://www.edcmag.com/articles/94991-leed-v4-built-to-perform>.

10. Kats, Greg. "The Costs and Financial Benefits of Green Buildings." CalRecycle.ca.gov. Sustainable Building Task Force, Oct. 2003. Web. 15 Oct. 2013. <http://www.calrecycle.ca.gov/greenbuilding/Design/CostBenefit/Report.pdf>.

11. Krotz, Joanna L. "Businesses Find Benefits in Going Green." Entrepreneur.com. Entrepreneur, 7 July 2013. Web. 15 Oct. 2013. <http://www.entrepreneur.com/article/227295>.

12. Maddison, Angus. "Statistics on World Population, GDP and Per Capita GDP, 1-2006 AD." Maddison Project. Groningen Growth and Development Centre, Mar. 2009. Web. <www.ggdc.net/maddison>.

13. Mazria, Edward E. "It's the Architecture, Stupid! Who Really Holds the Key to the Global Thermostat? The Answer Might Surprise You." Solar Today May/June (2003): 48-51. Publications. Mazria, Inc. Web. 9 Mar. 2014. 〈http://www.mazria.com/ItsTheArchitectureStupid.pdf〉.

14. Owens, Brendan, Chrissy Macken, Adam Rohloff, and Heather Rosenberg. LEED V4 Impact Category and Point Allocation Development Process. Rep. USGBC, n.d. Web. 10 Mar. 2014.

$<$ http://www.usgbc.org/sites/default/files/LEED\%20v4\%20Impact\%20Category\%20and\%20Point\%20Allo cation\%20Process_Overview_0.pdf>.

15. Quirk, Vanessa. "Where Is LEED Leading Us?...And Should We Follow?" ArchDaily.com. ArchDaily, 23 Apr. 2012. Web. 15 Oct. 2013. <http://www.archdaily.com/227934/>.

16. "Rating Systems." USGBC.org. USGBC, n.d. Web. 15 Oct. 2013. <http://www.usgbc.org/leed/ratingsystems>.

17. $\quad$ "Rainwater Management." USGBC.org. USGBC, n.d. Web. 15 Oct. 2013. <http://www.usgbc.org/node/2614803?return=/credits/schools---existing-buildings/v4>.

18. Schnaars, Christopher, and Hannah Morgan. "In U.S. Building Industry, Is It Too Easy to Be Green?" USAToday.com. USAToday, 13 June 2013. Web. 13 Mar. 2014.

<http://www.usatoday.com/story/news/nation/2012/10/24/green-building-leed-certification/1650517/>. 
19. Stott, Rory. "LEED V4: Better than the LEEDs That Came Before?" ArchDaily.com. ArchDaily, 2 Dec. 2013. Web. 10 Mar. 2014. <http://www.archdaily.com/452760/leed-v4-better-than-the-leeds-that-camebefore/>.

20. $\quad$ US Green Building Council. "Green Building Facts." US Green Building Council, Apr. 2009. Web.

21. Wustlich, Guido, Ruben Müller, and Hansjörg Radtke, eds. Heat from Renewable Energies: What Will the New Heat Act Achieve? Rep. Berlin: German Federal Ministry for the Environment, Nature Conservation and Nuclear Safety (BMU), July 2008. Print. 